\title{
Hate Speech During the Caliphate of 'Alī ibn Abì Tâalib and Its Relevance to Regulations in Indonesia: The Study of the Islamic Law History
}

\author{
Yayan Muhammad Royani \\ Universitas Islam Negeri Sunan Gunung Djati, Bandung - Indonesia \\ yayanmroyani@uinsgd.ac.id
}

\begin{abstract}
This paper aims to describe the process of overcoming hate speech crimes during the caliphate of 'Alī ibn Abī Tālib in the perspective of the history of Islamic law. The important question to be answered in this paper is how did the caliph 'Alī ibn Abī Tălib contribute to handling the problem of hate speech? This paper finds three essential things. First, the death of Caliph 'Uthmān became the cause of the emergence of various slander. The main perpetrators were the Sabā'iyyah, Khawarij, and Shia groups. The form of slander is in the form of hate speech, such as insulting, defaming, inciting, spreading hoaxes which are violations of human rights and have discriminated against certain entities and individuals. Second, the policy of overcoming hate speech is pursued by a criminal and social law approach. Third, the relevance between 'Alī ibn Abī Țālib's policy and existing regulations in Indonesia lies in the form of actions, punishments, and protection of human rights from discrimination
\end{abstract}

Keywords: hate speech; 'Alī ibn Abī Tālib; ta'ziri; the history of Islamic law

Tulisan ini bertujuan untuk mendeskripsikan proses penanggulangan kejahatan ujaran kebencian pada masa kekhalifahan 'Alī ibn Abī Tālib dalam kaca mata sejarah hukum Islam. Pertanyaan penting yang hendak dijawab pada tulisan ini yaitu bagaimana khalifah 'Alī ibn Abī Tạalib berkontribusi dalam penanganan masalah ujaran kebencian? Tulisan ini menemukan tiga hal penting. Pertama, kematian Khalifah 'Uthmān menjadi sebab kemunculan berbagai fitnah. Pelaku utamanya yaitu kelompok Sabaiyyah, Khawarij, dan Syiah. Bentuk fitnahnya berupa ujaran kebencian, seperti menghina, mencemarkan nama baik, menghasut, menyebarkan hoax yang merupakan pelanggaran terhadap hak asasi manusia dan telah mendiskriminasi terhadao entitas tertentu maupun individu. Kedua, kebijakan penanggulangan ujaran kebencian ditempuh dengan pendekatan hukum pidana dan sosial. Ketiga, Relevansi antara kebijakan 'Alī ibn Ảbī Tạalib dengan regulasi yang ada di Indonesia terletak dalam bentuk perbuatan, hukuman, dan perlindungan hak asasi manusia dari diskriminasi.

Kata Kunci: ujaran kebencian; 'Alī ibn Abī Țālib; ta'zīr; sejarah hukum Islam 
Yayan Muhammad Royani

\section{Introduction}

Hate speech has existed in Islamic history. In the era of the caliphate of 'Alī ibn Abī Tâalib, this phenomenon was increasingly widespread. The impact on the death of 'Uthmān ibn 'Affān. As caliph, 'Alī played a role in overcoming these crimes. The scholars, related to the provisions of the law on hate speech, group it into the type of ta'zir punishment. In line with the decision of the caliph 'Alī, Wahbah al-Zuhayli punished the perpetrators of hate speech with ta'zir punishment, not with hadd punishment. The hate speech in question is like saying yō kāfir, yā fäsiq, yā himimār to others. ${ }^{1}$

Hate speech crimes are not defined in Islamic law. It will not be found in the discussion of hadd and qișās punishment chapters, so the process of punishment is classified into the ta'zir type. Unlike common insults, hate speech is a type of crime that violates human rights and discriminates against certain groups. However, both hate speech and insults are forms of crime that deserve punishment.

Wahbah al-Zuhayli's opinion above strengthens al-Shāfi'yah's opinion which states that the words yō kāfir, yā fāsiq, yā shāqi, yā kalb, yā himimār, yā rāfid, yā khäbith, yā kadhdhāb, are punished with ta'zīr. Meanwhile, Hanafiyah argues that the words hi dog, hi pig, or hi donkey are not included in the type of ta'zir punishment. According to him, these words are different from hate speech but are classified as lies. ${ }^{2}$

Considering the harmful effects caused by hate speech crimes, understanding and legal history are needed to contribute to effective prevention. Several studies have been conducted on hate speech. Saeed Mohammed Alzahrani, in his dissertation, has discussed hate speech from a general fiqh perspective. ${ }^{3}$ However, he did not explain the correlation between hate speech and freedom of expression, which is a misunderstanding among the ulama. It also does not describe a factual analysis of the process of hate speech occurring and developing during the caliphate of 'Alī ibn Abī Taallib.

\footnotetext{
${ }^{1}$ Abū Bakr Ahmad ibn Ḥusayn ibn 'Alī al-Bayhaqī, Al-Sunan al-Kubrā (Beirut: Mu’assasah al-Ṭibā’ah wa al-Tașwir, n.d.), vols V; 258; Wahbah Al-Zuhaylī, Al-Fiqh al-Islāmī wa Adillatuh, 2nd ed. (Damaskus: Dār al-Fikr al-'Arabī, 1985), 197-98.

2 Al-Zuhaylī, Al-Fiquh al-Islāmī wa Adillatuh, 198.

${ }^{3}$ Saeed Mohammed Alzahrani, 'Hate Speech from the Traditional Islamic Perspective' (The Indiana University, 2017), https://doi.org/10.2/JQUERY.MIN.JS.
} 
Atikah Marwa and Muhammad Fadhlan, in their research, explain the law regarding the phenomenon of hate speech on social media. ${ }^{4}$ Meanwhile, Yani'ah Wardhani and Ekawati provide information about hate speech related to the three domains of perception, response, and impact of religion-based hate speech in Jakarta, Bekasi, and Banten. ${ }^{5}$ Meanwhile, Asphianto compares positive and Islamic law without looking at the history of the formation of the law. ${ }^{6}$ Thus, this paper is different from previous studies. The main focus of this paper is on the phenomenon of hate speech that occurred during the caliph 'Alī, the process of overcoming it, and its relevance to events and existing laws in Indonesia.

Hate speech has been regulated in various regulations and the ratification of international treaties in Indonesia. However, it did not have a significant impact in overcoming the crime. Hate speech still happens, even by religious leaders. This crime needs attention so that the realization of justice and order can be appropriately realized. The phenomenon that occurred during the caliphate of 'Alī, thus found its importance.

There is relevance to 'Alī ibn Abī Taalib's opinion on hate speech with the Criminal Code and other regulations. The bearing includes definitions, forms of speech and punishment, as well as protection of human rights. The two clauses $y \bar{a}$ kăfir yō himār can be described in two forms of speech. The first is to attack someone's belief that violates the Human Rights entity. The second refers to attacks on individual honour. The form of punishment for both acts is $t a^{\prime} z i r$.

This paper examines hate speech crimes through library research using a normative juridical approach to positive legal data. ${ }^{7}$ The normative juridical approach is used by analyzing secondary data in legal materials, especially

${ }^{4}$ Atikah Marwa and Muhammad Fadhlan, 'Ujaran Kebencian di Media Sosial Menurut Perspektif Islam', Al-Afkar Journal for Islamic Studies 4, no. 1 (4 March 2021): 1-14, https://al-afkar.com/index. php/Afkar_Journal/article/view/140.

5 Yani'ah Wardani and Ekawati Ekawati, 'Ujaran Kebencian Berbasis Agama: Kajian Persepsi, Respon, dan Dampaknya di Masyarakat', Buletin Al-Turas 26, no. 1 (10 February 2020): 153-71, https://doi.org/10.15408/BAT.V26I1.13698.

${ }^{6}$ Aan Asphianto, 'Ujaran Kebencian dalam Sudut Pandang Hukum Positif dan Islam', Al-Risalah 17, no. 1 (17 January 2018), https://doi.org/10.30631/AL-RISALAH.V17I01.3.

7 Sutrisno Hadi, Metodologi Research (Yogyakarta: Fakultas Psikologi Universitas Gadjah Mada, 1990), 15. 
primary legal materials and secondary legal materials. It is used to understand the law as a set of rules that govern human life. 8

The historical approach of Islamic law is also used to find out the background of the formation of law at that time. Historical is used to see events related to hate speech and conduct a legal analysis of the periodization sequence and the historical facts behind it. ${ }^{9}$ The historical approach to forming Islamic law (tārikk al-tashrī) looks at history, culture, law, and politics. It seeks to understand a phenomenon, observe changing trends and dynamics of Islamic law, and the factors that influence it.10

The main question of this paper is how did Caliph 'Alì ibn Abī Țâlib make an important contribution in dealing with the problem of hate speech? These questions are assisted by several minor questions as follows. 1 . What is the context of the emergence of hate speech during the time of 'Alì ibn Abī Tâlib? 2. How did Caliph 'Alì ibn Abī Tâalib deal with this problem? 3. How is it relevant to regulations in Indonesia? 4. What is the contribution of 'Alī ibn Abī Țālib's thoughts in tackling hate speech in Indonesia?

\section{Hate Speech During the Caliphate of 'Alī ibn Abī Ṭālib}

Slander and hate speech have occurred in every era. In the era of the Prophet, a cruel slander had befallen 'Ā'ishah. He was accused of adultery. This baseless accusation caused a stir in Medina at that time. In addition to making him sad, the incident also made the Prophet worried. Because of this slander, as well as revelations from God never came to give an answer. The Prophet then discussed with Osama and 'Alī. Osama responded that 'A''ishah was innocent so she could still be trusted. Meanwhile 'Alī stated that for the good of the Prophet, the Prophet should divorce her.11

'Ali bases his suggestion on the least likely of the two dangers to occur. According to him, if the Prophet remains restless, the Muslims and the message are at stake. According to al-Nawāwī, as quoted by Shalllabi, 'Alī's offer would

\footnotetext{
${ }^{8}$ Soerjono Soekanto and Sri Mamudji, Penelitian Hukum NormatifSuatu Tinjauan Singkat (Jakarta: RajaGrafindo Persada, 2011), 14.

9 Johan Nasution, Metode Penelitian Ilmu Hukum (Bandung: Mandar Maju, 2008), 81.

10 Yayan Sofian, Tarikh Tasyri' Sejarah Pembentukan Hukum Islam (Jakarta: Rajawali Press, 2018), 17.

11 Muhammad Ibn Ismāîl al-Bukhārī, Șahīhal-Bukhārī (Riyad: Bayt al-Afkār al-Dawliyyah li alNashr wa al-Tawzī', 1997), 1016 Hadith Number 4141.
} 
benefit the Prophet. 'Alī believed that his advice could calm the Prophet in times of great turmoil. 12

Hate speech during the time of Abū Bakr stems from his disagreement about the postponement of 'Alì's promise. There is an opinion that 'Ali did not pledge allegiance to Abū Bakr because he was still mourning the death of the Prophet. 'Alī took a commitment to Abū Bakr after the completion of the Prophet's funeral procession. He asked Sa'îd ibn Zayd "Did you witness the death of the Prophet?" Sa'īd replied, "yes."13

Hate speech also hit 'Umār ibn al-Khațāa. It comes from the Shia Imāmiyah group who hates the companions. In a narration, Aslam Al-Adawi explains that when the Prophet died, 'Umār and Zubayr ibn 'Awwam went to Fāțimah to invite her to consult. 'Umār said, "O daughter of the Prophet! There is no one we love more than your father. Furthermore, there is no human after your father whom we love more than you."14

Slander also occurred during the time of 'Uthmān bin 'Affān. It was motivated by various interrelated events. According to Shallabi, these factors are the luxuries that affect society, the departure of senior companions from Medina, the fanaticism of ignorance, the alliance of envious people, the use of means and media to provoke the masses, and the influence of the Sabāiyyahyah sect. 15

Shallabi stated that the Saba'iyyah led by 'Abdullāh ibn Sabā' spread hate speech among Muslims. The crime was not only carried out verbally; even fake letters were circulated in the name of the Caliph and other companions. The case considered the cause of chaos and the most heinous slander against the Caliph 'Uthmān is when the rebels who came to Medina had made peace with the Caliph. ${ }^{16}$ The existence of 'Abdullāh ibn Sabā' has been mentioned in various ahl al-sunnah books. Al-Sha'bī (d. $103 \mathrm{AH}$ ) relates that the first to lie was 'Abdullāh

\footnotetext{
12 Ali Muhammad Al-Shallabi, Biografi Ali Bin Abi Thalib (Jakarta: Ummul Qura, 2017), 187-90.

13 Muhammad ibn Jarīr Al-Ṭabarī, Tārīkh al-Umam wa al-Mulūk (Beirut: Dār al-Fikr, 1987), vols III; 207.

14 Ibn Abī Shaybah, Al-Mușannaf, 1986, vols XVII; 567.

${ }_{15}$ Al-Shallabi, Biografi Ali Bin Abi Thalib, 319.

16 Al-Shallabi, 321.
} 
Ibn Sabā'. Ibn Ḥabīb (d. 245 H) narrates that Ibn Sabā' is one of Habashah's children. ${ }^{17}$

'Abd al-'Aziz argues that the Khawarij emerged because of the disappointment of some people with 'Ali's decision during the Siffin war. At that time, they regretted 'Alī's decision to accept Mu'āwiyah's invitation to make peace (tahkim). They were disappointed that'Alīhesitated with the help of those who could defeat the opponent but instead chose tahkim. They then changed their view that everyone involved in the tahkim event was kufr. Whoever accepts it has become an infidel and must repent. ${ }^{18}$

As for the Shia, they accuse the companions of being unfair in determining the affairs of Muslims. 'Alī was considered unwilling if 'Abd al-Rahmān ibn 'Awf became chairman of the deliberative council in the election of the caliph. As quoted by Shallabi according to the narrations of Abū Mukhannaf and Hisham Al-Kalaby that 'Umār would still not win 'Abd al-Rahmmān ibn 'Awf. Therefore 'Alī already felt that he would lose the caliphate because 'Abd al-Rahmān ibn 'Awf would put 'Uthmān first.'19

'Alī classifies forms of hate speech as insults, defamation, incitement, spreading false news. It is a violation of human rights and discrimination based on certain entities or individuals. 'Alī argued about the prohibition of various forms of humiliation, defamation, and blasphemy of religion. The state of contempt refers to his statement that leaving insulting words will gain the pleasure of Allah, anger the devil, and be a punishment for the enemies. ${ }^{20}$ 'Ali also believed that any form of terror, if it resulted in the loss of a person's life, then he was responsible for the crime.21 As for the spread of hoax, 'Alī

17 Sulaymān ibn Fahd Al-'Awd, 'Abdullāh bin Sabā' wa Atharuh fi Ahdāth al-Fitnah fi Sadr al-Islām (Dār al-Taybah, 1412), 53, https://books-library.net/files/elebda3.net-wq-5121.pdf.

18 'Abd al-'Azīz ibn 'Abd Al-Humaydī, Al-Khulafā' al-Rāshidūn Mawāqif wa 'Ibar (Iskandariyah: Dār al-Da'wah, 2005), 670, https://down.ketabpedia.com/files/bkb/bkb-hi03517-ketabpedia.com.pdf.

${ }^{19}$ Al-Shallabi, Biografi Ali Bin Abi Thalib, 311.

20 Ghassān Al-Sa'd, Huqūq Al-Insān 'ind al-Imām 'Alī Ibn Abī Țālib 'Alayh al-Salām Ru'yah 'Ilmiyah (Baghdad, 2008), 652, http://www.alnoor.se/article.asp?id=58783.

${ }^{21}$ Syekh Syarif Radhi, Nahjul Balaghah, Puncak Kearifan Sepanjang Masa (Yogyakarta: Diva Press, 2020), 189. 
emphasized to avoid prejudice against people who believe because Allah has given the truth to their words. ${ }^{22}$

'Ali emphasized that human rights cannot be separated from the rights of equality and justice. According to him, there is no difference in rights between humans in the view of sharia. The protection of the rights of human life is in line with the creation of a sense of security in society. ${ }^{23}$ 'Ali stated that humans are brothers in religion, and all are equal in their existence as human beings. ${ }^{24}$

\section{'Alī ibn Abī Ṭālib Policy in Regulating Hate Speech}

In order to regulate and prevent crime, 'Alī ibn Abī Ṭālib used four methods:

1. Using a criminal law approach.

2. The social policy approach.

3. Using a repressive legal system.

4. Implement preventive actions and other policies.

All these methods he uses in order to achieve justice and benefit. According to Nawawi Arief, the criminal policy can be interpreted as a reasonable government effort to tackle crime. It is an inseparable part of efforts to protect the community and achieve community welfare. ${ }^{25}$

The criminal law policy regarding hate speech can be seen from 'Alī's words when asked about the comments yō kāfir, yō khābith, and yō himār being punished as ta'zir. Because this type of verbal crime is not regulated in the texts, the authorities are given the freedom to determine the type and form of punishment.

The social policy approach is based on ethical values, benefits, and the protection of human rights. As an expert in science, 'Ali gave sermons on the dangers of oral speech and the importance of guarding human dignity. When dealing with slandered people, 'Alì's action is to advise and provide the correct view of the nature of the problem. Facing the Khawarij who went out of line and

22 'Alī ibn Muhammad al-Layth Al-Wāsiț̣, 'Uyūn al-Hukm wa al-Mawāo'ị (Dār al-Ḥadīth, 2000), 88, https://hz.turathalanbiaa.com/public/3103.pdf.

${ }^{23}$ Al-Wāsițī, 215.

24 Radhi, Nahjul Balaghah, Puncak Kearifan Sepanjang Masa, 547.

25 Barda Nawawi Arief, Bungan Rampai Kebijakan Hukum Pidana, ke 5 (Jakarta: Kencana, 2014), 3. 
considered the Muslims infidels, 'Alī gave freedom as long as they did not interfere and fight other Muslims.

Muslims place the companions of the Prophet as figures who should be exemplary. Those with authority are expected to contribute their thoughts to answer the methodological and philosophical deadlocks related to the hate speech law. 'Alī ibn Abī Țālib as a șahābah and caliph has an essential position as a mujtahid and qā

As a $q \bar{a} d \underline{1} \overline{1}$, 'Alī uses several approaches. First, sourced from the Qur'an and Sunnah. The method of taking arguments from the Qur'an begins with glorifying it, then understanding it with the scientific method.27 'Ali understood the Sunnah directly from the Prophet by keeping an example of the Prophet's words and actions. He maintains the integrity of the Sunnah by memorizing and writing it down. He also looked at the Sunnah from a scientific point of view based on its text, purpose, and conformity to the Qur'an.28

The legal istinbat method used by 'Alī also refers to ijmā' and pre-Islamic sharī'ah (shar' man qablanā). In addition to the naqlī method, 'Alī used the reasoning process with the qiyās, istihsān, and istișhāb methods. 'Alī also used ijtihād maqāṣidī in deciding some cases. ${ }^{29}$ According to 'Abdullāh ibn Sulaymān ibn 'Alī, 'Alī's method of ijtihād thought was adopted by many educational institutions in Kūfah. 30

'Alī ibn Abī Ṭālib based his maqāṣidī method on the benefit side by considering 'urf (custom) and sadd al-dhari'ah (preventive action). ${ }^{31}$ It considers the beneficial and harmful effects of an action. Maqāșid himself places

26 'Abdullāh ibn Sulaymān ibn 'Alī al-'Abd Al-Mun'ïm, 'Fiqh Amīr al-Mu'minīn 'Alī Ibn Abī Ṭālib fỉ alHudūd wa al-Jināyāt wa Athruh fî Tashrī al-Jināī al-Islāmı̂̉ (Jāmi'ah Nāyif al-'Arabiyah li al-'Ulūm alUmniyah , 2004), 7, https://ia903400.us.archive.org/30/items/fiqh07001/fiqh07713.pdf.

27 Muhammad Fu'ād Ḍāhar, Aqḍiyyah al-Khalīfah al-Rāshid 'Alī Ibn Abī Ṭālib, Dirāsah Ta'șiliyah Tatbiqqiyah li Manhaj 'Alī fi Usūl al-Fiqh, 1st ed. (Kuwait: Mabarrah al-Āl wa al-Aṣhāb, 2015), 179-201, https://d1.islamhouse.com/data/ar/ih_books/single_01/ar_Aqdit_Ali_ibn_Abu_Talib.pdf.

28 Dāhar, 236.

29 Ḍāhar, 267-365.

${ }^{30}$ Al-Mun'im, 'Fiqh Amīral-Mu'minīn 'Alī Ibn AbīṬālibfial-Hudūd wa al-Jināyāt wa Athruh fí Tashrī al-Jināîal-Islāmî̀, 5 .

31 Ḍāhar, Aqdiyyah al-Khalīfah al-Rāshid 'Alī Ibn Abī Tậlib, Dirāsah Ta'șiliyah Tațiiqiyah li Manhaj 'Alī fiussūlal-Fiqh, 367. 
al-mașlahah as the primary goal of Islamic law. It is as al-Shāțibi's opinion which states that maqāșid places benefit as an essential element of legal goals. ${ }^{32}$

'Alì's thoughts on fiqh and ușūl al-fiqh greatly influenced the development of the science of fiqh. Al-Shāfi'i states that if it were not for 'Alī, there would be no law on bughat. ${ }^{33}$ Meanwhile, Al-Dihlawī stated that the basis of the school of Abū Hanifah is the fatwa of 'Abdullāh ibn Mas'ūd and the decisions and fatwas of 'Alī ibn Abī Țālib. ${ }^{34}$

\section{The Relevance of 'Alī ibn Abī Ṭālib's Policy regarding Hate Speech and Regulations in Indonesia}

Hate speech has the potential to divide the unity and integrity of Indonesia. Although many laws and regulations regulate it, the implementation and enforcement of the law have not been effective. Several regulations related to hate speech in Indonesia are; Law No. 1 of 1946 concerning the Criminal Code, Law No. 39 of 1999 concerning Human Rights, Law No. 40 of 2008 concerning the Elimination of Race and Ethnic Discrimination, Law No. 11 of 2008 concerning Information and Electronic Transactions. Hate speech is also clearly regulated in the Circular Letter of the National Police Chief number SE/06/X/2015. Hate speech cases that arise often involve identity politics which causes social, vertical, and horizontal conflicts. The primary source of regulations governing hate speech is Article 156 of the Criminal Code. Hate speech is prohibited in public to express hostility, hatred, or contempt towards community groups in Indonesia. ${ }^{35}$

Meanwhile, the prohibition of hate speech in cyberspace is strictly regulated in Article 28 paragraph (2) of Law No. 11 of 2008 concerning Information and Electronic Transactions. A person is prohibited from spreading information that aims to cause hatred or hostility based on ethnicity, religion, race, and class. Hate speech is theoretically defined as a crime in the form of swearing, insulting, defaming individuals or groups based on ethnicity, nationality, race, gender,

\footnotetext{
215.

${ }^{32}$ Abu Rokhmad, Ushul Fiqh Metodologi Ijtihad Hukum Islam (Semarang: Varos Mitra Utama, 2002),

33 Muhammad al-Khațỉb al-Shirbīnī, Mughnī al-Muhtāj (Beirut: Dār Al-Kutub Al-'Ilmiyyah, 2000), vols IV; 123.

${ }^{34}$ Shah Waliyullāh al-Dihlawī, Hujujah al-Bälighah (Riyad: Maktabah al-Kawthar, 1999), vols I; 448.

35 Moeljatno, KUHP Kitab Undang-Undang Hukum Pidana (Jakarta: Bumi Aksara, 2006), 115.
} 
sexual orientation, or religion. It results in hostility and intimidation towards the object of the action. 36

Based on the 1966 International Covenant on Civil and Political Rights (ICCPR) Article 20 Paragraph 2, states are prohibited from taking sides and advocating acts of hate speech or incitement to discrimination that can lead to hostility and violence based on race or religion. ${ }^{37}$ However, the Article on hate speech does not regulate in detail the forms of hostility, hatred, or humiliation. Thus, according to Andi Hamzah, the judge has the authority to interpret the action. This Article is considered ambiguous because of its bias and vulnerability to politics outside the law. This Article is considered to contain an element of emotion.

'Ali's opinion with regulations in Indonesia regarding hate speech both contain a prohibition against hate. 'Ali declared that enmity with fellow human beings is a heinous act. ${ }^{38} \mathrm{He}$ continued that those hostile are the same as having made Satan the ruler of their affairs. Satan has overpowered them, sees with his eyes, and speaks with his tongue. ${ }^{39}$ This expression forms the basis for a ban on hate speech.

The formulation of acts of hate speech in Islam goes beyond the scope of regulatory definitions and Western terms. The moral principle that underlies the prohibition of hate speech applies to other actions related to the benefit of the people. First, the prohibition against hating other people, both fellow Muslims and non-Muslims. Subjectively, a Muslim is prohibited from having feelings of hatred or committing acts of humiliation to others. As for objectively, religion forbids any actions that harm others.

The second principle, hate speech, relates explicitly to the prohibition of saying words that cause personal or group hostility. It includes words and actions directed at a Muslim or non-Muslim. Islam forbids discrimination on any basis so that there should be no difference in viewing God's creation. Islam

\footnotetext{
${ }^{36}$ Susan J. Brison, 'The Autonomy Defense of Free Speech', Ethics 108, no. 2 (January 1998): 313, https://doi.org/10.1086/233807/0.

37 William B. Fisch, 'Hate Speech in the Constitutional Law of the United States', The American Journal of Comparative Law 50 (2002): 463, https://doi.org/10.2307/840886.

38 Ḥammad Muhammad 'Abd Al-Ṣamad, Niz̄ām al-Hukm fi 'ahd al-Khulafä' al-Rāshidīn (Beirut: Mu'assasah al-Jāmi' iyyah li al-Dirāsāt wa al-Nashr wa al-Tawzī, 1994), 165.

${ }^{39}$ Aḥmad ibn Yaḥyā ibn Jābir Al-Balādhrī, Jumal min Insāb al-Ishrāf (Beirut: Mu’assasah al-I'lāmī, 1973), 701.
} 
highly upholds human rights based on respect for differences. Islam does not distinguish forms of hate speech based on discrimination against human rights entities and ordinary forms of humiliation. 'Alī states that the words $y \bar{a} k \bar{a} f i r, y \bar{a}$ fāsiq, yā himār are condemned as ta'zir. These words are a form of insult based on belief and cursing.

'Alī ibn Abī Țālib prohibited some of the actions: insults, slander, blasphemy, incitement, provocation, spreading hoaxes, insulting the sahaba, and damaging the honor of the Islamic religion. Acts that are considered not to be included in hate speech but are prohibited by 'Alī are cursing and slandering. While cursing is categorized as expressing hostility when viewed from praying for someone in a state of anger. In contrast to insulting, cursing requires a more profound identification because it intersects with freedom of expression. Praying for evil is included in expressing someone's beliefs that are considered contrary to the teachings they believe.

As for ghïbah, which is talking about someone that person does not want to hear, it is the same as spreading someone's disgrace. It was done, both secretly and openly. Backbiting can still be categorized as an insult, even though it is accurate. The desirable element is caused not only by untrue accusations but also includes remarks that attack honor. Such misdeeds are punishable by imprisonment and fines, which policymakers determine with a series of conditions. In Islam, the punishment that is left to the policymakers is called $t a^{\prime} z \bar{r}$. That is the relevance between the existing regulations in Indonesia and the decision of 'Ali.

According to 'Abd al-Qādir 'Awdah, jarīmah ta'zīr is a criminal act that can be punished with a single or more punishment based on ta'zirr. Ta'zir itself means destiny or discipline. According to 'Awdah, sharīah does not provide a limit on the sentence for jarimah ta'zīr. The ta'zir punishment decided by the judge can be based on appropriateness based on the act and the perpetrator. So, the $t^{\prime}$ 'zir punishment is based on the judge's consideration. ${ }^{40}$

In determining a crime, 'Alī used ijtihad maqāsidī. According to Fu'ād Ḍāhar sources of ijtihād maqāsidi 'Alī are:41 al-mașlaḥah al-mursalah, al-kulliyah al-

40 'Abd al-Qādir 'Awdah, Al-Tashrī’ al-Jināî̀ al-Islāmī Muqāran bi al-Qānūn al-Waḍ̂̀ (Beirut: Mu'assasah al-Risālah, 2001), 80.

41 Ḍāhar, Aqụiyyah al-Khalīfah al-Rāshid 'Alī Ibn Abī Țālib, Dirāsah Ta’ṣiliyah Taṭbìqiyah li Manhaj 'Alī fiUșūl al-Fiqh, 407. 
khamsah, al-'urf, and sadd al-dhari'ah. The basis of benefit in the protection of human rights are 1). right to life, 2). the right to equality and justice 3 ) the right to freedom. ${ }^{42}$

'Ali's protection of human rights entities is relevant to the provisions contained in Indonesian regulations. 'Ali bases the protection of human rights on the concepts of justice and equality. Both are categorized into two parts: the equality of human entities with human ties (ukhuwah insāniyah) and putting something in its place. When 'Alī was asked which is better, generosity or justice, he replied that justice puts something in its place while generosity brings something out according to its direction. ${ }^{43}$.

'Ali prohibited discrimination based on belief with his policy at the time. He stated that when faced with a case, he would use the Torah law for its adherents, use the Bible law for its adherents, and use the Qur'an for Muslims. ${ }^{44}$ Faith is a fundamental right that cannot be imposed on others. The Qur'an expressly states that everyone has the right to their own beliefs, as stated in QS. 109. He also prohibits discrimination based on sex or persons with special needs. He respects women as he respects Fātimah. His concern for people with special needs is to implement policies that provide equal services to all levels of society.

\section{The Contribution of 'Alī ibn Abī Țâlib's Thoughts to the Resolution of Hate Speech in Indonesia}

First, the linguistic contribution, where the linguistic approach by 'Alī refers to the 'urf. An example of 'Alì's use of 'urf is on the issue of the benefit of al-illa' for a wife. Someone told his wife to breastfeed his brother's child with his child. His wife replied that she couldn't breastfeed two people. So the man promised not to approach his wife until the end of breastfeeding. After that, the man went to the assembly, so people asked the man why he didn't feed the child. The man replied that he promised not to approach his wife until the end of breastfeeding. So people said to him that it was al-ila $\bar{a}^{\prime}$.

Then 'Alī came and explained that if the words were done out of anger then the person was forbidden to come to his wife, while if not then he was allowed

\footnotetext{
${ }^{42}$ Al-Sa'd, Huqūq al-Insān 'ind al-Imām 'Alì Ibn Abī Tạalib 'Alayh al-Salām Ru'yah 'Ilmiyah, 31.

${ }^{43}$ Al-Sa'd, Huqūq al-Insān 'ind al-Imām 'Alì Ibn Abī Ṭālib 'Alayh al-Salām Ru'yah 'Ilmiyah, 75.

44 Muhammad ibn Mas'ūd al-'Ayyāshī, Al-Tafsīr al-'Ayyāshī (Teheran: Maktabah al-Ilmiyah alIslāmiyah, n.d.), vols I; 15.
} 
to go to his wife. In other literature, 'Alī has also said that there is an element of anger in $a l-\bar{l} l \bar{a}$ '. In that case, 'Alī did not see from the language used, but saw from the intentions of the person. What the man wants is for the benefit, while al-ila is for harm. 45

Second, the contribution of the ethical approach. Religion and values or ethics have a close relationship, but the beliefs of one religion are very difficult to coexist with others. Even so, ethical norms between one religious follower and another often have similarities. Morality as a basis cannot exist without religion, although the morality that is practiced is not necessarily related to religiosity. So that every transformation of morality, also begins with religious renewal.

Islam is deeply committed to moral wisdom, compassion, character of honesty and justice. Humans are directly mandated to become caliphs on earth to uphold justice. In the Qur'an there are several ethical concepts of ma'rüf, alkhayr, al-birr, al-haq, al-qist, ihsān, and älihah. Apart from that, there are amr ma'rüf nahy munkar (hisbah) deeds, ta'āwun, ukhuwah, humanization, and efforts for social welfare. The most important thing is patience and knowledge. ${ }^{46}$

'Alì's advice is related to speaking ethics, including 'Alī's opinion to stay away from every action that the perpetrator likes for himself but is not liked by Muslims in general. Steer clear of any actions that are carried out in secrecy and which may cause embarrassment when exposed. Stay away from actions that when the perpetrator is asked about it, he himself views it as bad or he makes excuses for it. Does not open the honor to be the subject of people's conversation. Avoid telling people everything that is heard, because it will lead to falsehood. Forbidding to match everything that people say, because it means stupidity. 47

'Ali's advice about speaking ill of others is his opinion that the gossiper is the one who blames his brother and finds fault with him. One should remember that Allah has hidden his sins. In fact, it could be that the person's sins are greater

\footnotetext{
${ }^{45}$ Al-Ṭabarī, Tārïkh al-Umam wa al-Mulūk, vols IV; 133.

46 Mohammad Hashim Kamali, 'Ethical Limits on Freedom of Expression with Special Reference to Islam', Cile Journal, 2014, 45, https://www.cilecenter.org/sites/default/files/pdfs/RecommendedArticles-English-Ethical-Limits-on-Freedom-of-Expression.pdf.

${ }^{47}$ Al-Rāạī, Nahju al-Balāghah, vols III; 189.
} 
than the sins of his brother. Every human being must have sinned. Therefore, Islamic values teach not to spread someone's ugliness without a clear basis. ${ }^{48}$

During the battle of Siffin, 'Alī heard some of his men berating the Syrians. So 'Alī said that he didn't like the behavior. Next, 'Alī asked to better describe their actions and tell them their situation, that was a better way of speaking and a more convincing way of arguing. Instead of insulting them, it would be better if you ask Allah for help. ${ }^{49}$

The ethical approach is in accordance with the Circular Letter of the National Police Chief number SE/2/11/2021 concerning Ethical Cultural Awareness to Create a Clean, Healthy, and Productive Digital Space for Indonesia. In law enforcement efforts, the police are asked to use persuasive, educative and preventive measures. To uphold justice, it is necessary to understand the ethical culture of the community in communicating on social media.

Third, the contribution of the unified and unified approach. As the Prophet kept the unity and unity, the companions including 'Alì ibn Abì Tâalib certainly followed in his footsteps. Hate speech as part of actions that can cause division and unity has emerged since the time of the Prophet. 'Abdullāh ibn Ubay ibn Salūl is a person who is considered to be the spreader of rumors about 'A''isha's adultery. Responding to this, the Prophet did not immediately respond in a hurry, but was very careful and thoroughly investigated the case. The Prophet asked his companions for consideration, including 'Alī. Even though at that time, 'Ali gave the opinion that the Prophet should divorce 'A''ishah, for the benefit of her, not out of hatred for 'Â'ishah. However, 'Ali took a lesson from the Prophet's prudence in responding to the slander over the killing of 'Uthmān.

If this case is contextualized at this time, it is with the widespread spread of hoaxes. Hoax according to Irfan Afandi refers to information that is actually not true, but is made as if it is true.. ${ }^{50}$ The way to respond to the news circulating is to not be in a hurry to believe and participate in spreading it. A more in-depth examination is needed to find out the truth. The public is expected to master literacy so that they do not easily believe all the news that is spread.

\footnotetext{
48 Al-Rādī, vols II; 49.

${ }^{49}$ Al-Rādìi, vols II; 273.

50 Irfan Afandi, 'Hoax dalam Sejarah Islam Awal (Kajian Kritis tentang QS. An-Nur: 11-12)', ArRisalah: Media Keislaman, Pendidikan dan Hukum Islam 16, no. 1 (3 April 2018): 145-61, http://ejournaliaiibrahimy.acid/index.php/arrisalah/article/view/150.
} 
In maintaining unity and integrity, 'Alī obeyed the legitimate leader. Answering the hoax about the feud between 'Alī and Abū Bakr can refer to a history from Abū Sa'îd Al-Khuḍrī, which explains the events after the Prophet died. The Ansor group began to speak at Thaqifah's bay'at event. Then Abū Bakr looked at the audience who did not find 'Alī. Not long after, 'Alī came to take an oath of allegiance to Abū Bakr. ${ }^{51}$

\section{Conclusion}

The slander that sowed hate speech during the Caliphate of 'Alī ibn Abī Țālib started with the slander of the killing of 'Uthmān. The main actor in the spread of hate speech is 'Abdullāh ibn Sabā’ and his followers called the Sabā'iyyahyyah. Apart from Sabāiyyahyyah, there are Khawarij who came out of the ranks of 'Alī ibn Abī Țālib with a takfirī ideology. Shia Imāmiyah who glorify 'Alī excessively and denounce the companions and previous caliphs. The forms of hate speech according to 'Ali include insults, pollution, blasphemy, prohibition of cursing, backbiting, inciting and provocation, spreading hoaxes and false news, and insulting the five constants of Islam. All of these actions were prohibited by 'Alī based on words and actions in accordance with the arguments of the shari'ah. According to 'Alī, hate speech is a limitation on a person's freedom of expression because it is contrary to human values and human rights.

'Alì uses a criminal and social law approach in solving the problem of hate speech. The criminal law policy is in the form of prohibition of infidel or insulting words with bad nicknames. 'Alī punished him with ta'zir according to the ruler's policy. The social approach includes ethics, justice and the protection of human rights and strengthens unity. Analysis of 'Alī's ijtihād method in determining hate speech acts is based on the Qur'an, Sunnah, $i j m \bar{a}$ ', and qiyās. As for the provisions of the form of action and punishment using a ta'zir approach. To see the purpose of the shari'ah on the protection of human rights and the limitations of freedom of expression in achieving the benefit by using maqāṣid al-sharīah.

The relevance of 'Ali's opinion on hate speech with regulations in Indonesia can be seen from the definition, form of action, form of punishment and protection of human rights. First, basically an explicit definition of hate speech is not found in Indonesian regulations. However, from a theoretical point of view, there is relevance to 'Alī's opinion. The definition of hate speech according to 'Alī

${ }^{51}$ Al-Shallabi, Biografi Ali Bin Abi Thalib, 242. 
is the prohibition of expressing something that can cause hatred and hostility. Second, the form of action contained in the regulations in Indonesia is in accordance with 'Alì's opinion on hate speech. The actions that were prohibited by 'Alī were insults, slander and blasphemy, incitement and provocation, spreading hoaxes and false news. Third, the form of punishment set by 'Alī is ta'zir. The form of punishment for hate speech can be adjusted to the effectiveness of countermeasures while still paying attention to the benefit and protection of human rights.

Based on the above study, it is suggested to the government to reform the criminal law on hate speech by taking into account the limitations of human rights proportionally. With these two approaches, it is expected to provide the legal certainty needed to minimize juridical problems. In tackling hate speech, apart from using a penal method, a non-penal approach is needed by making non-discriminatory policies and prioritizing morality.[a]

\section{BIBLIOGRAPHY}

Afandi, Irfan. 'Hoax dalam Sejarah Islam Awal (Kajian Kritis tentang QS. An-Nur: 11-12)'.Ar-Risalah: Media Keislaman, Pendidikan dan Hukum Islam 16, no. 1 (3 April 2018): 145-61. http://ejournal.iaiibrahimy.ac.id/index.php /arrisalah/article/view/150.

Alzahrani, Saeed Mohammed. 'Hate Speech from the Traditional Islamic Perspective'. The Indiana University, 2017. https://doi.org/10.2/ JQUERY.MIN.JS.

Arief, Barda Nawawi. Bungan Rampai Kebijakan Hukum Pidana. Ke 5. Jakarta: Kencana, 2014.

Asphianto, Aan. 'Ujaran Kebencian dalam Sudut Pandang Hukum Positif dan Islam'. Al-Risalah 17, no. 1 (17 January 2018). https://doi.org/10. 30631/AL-RISALAH.V17I01.3.

Al-'Awd, Sulaymān ibn Fahd. 'Abdullāh bin Sabā' wa Atharuh fi Ahdāth al-Fitnah fi Șadr al-Islām. Dār al-Țaybah, 1412. https://books-library.net/files/ elebda3.net-wq-5121.pdf.

'Awdah, 'Abd al-Qāạīr. Al-Tashrī' al-Jinā'î al-Islāmī Muqāranan bi al-Qānūn alWaḍìi. Beirut: Mu'assasah al-Risālah, 2001. 
Al-'Ayyāshī, Muhammad ibn Mas'ūd. Al-Tafsīr al-'Ayyāshī. Teheran: Maktabah al-Ilmiyah al-Islāmiyah, n.d.

Al-Balādhrī, Aḥmad ibn Yahyā ibn Jābir. Jumal min Insāb al-Ishrāf. Beirut: Mu'assasah al-I'lāmī, 1973.

Al-Bayhaqī, Abū Bakr Aḥmad ibn Ḥusayn ibn 'Alī. Al-Sunan al-Kubrā. Beirut: Mu'assasah al-Ṭibā'ah wa al-Tașwīr, n.d.

Al-Bukhārī, Muhammad Ibn Ismāîl. Șahịh al-Bukhārī. Riyad: Bayt al-Afkār alDawliyyah li al-Nashr wa al-Tawzì', 1997.

Brison, Susan J. 'The Autonomy Defense of Free Speech'. Ethics 108, no. 2 (January 1998): 312-39. https://doi.org/10.1086/233807/0.

Ḍāhar, Muhammad Fu'ād. Aqḍiyyah al-Khalīfah al-Rāshid 'Alī ibn Abī Ṭālib, Dirāsah Ta'șīliyah Tațbiqqiyah li Manhaj 'Alī fi Ușūl al-Fiqh. 1st ed. Kuwait: Mabarrah al-Āl wa al-Aṣhāb, 2015. https://d1.islamhouse.com/data/ ar/ih_books/single_01/ar_Aqdit_Alī_ibn_Abu_T'Alīb.pdf.

Al-Dihlawī, Shah W'Alīyullāh. Hujjah al-Bālighah. Riyad: Maktabah al-Kawthar, 1999.

Fisch, William B. 'Hate Speech in the Constitutional Law of the United States'. The American Journal of Comparative Law 50 (2002): 492. https://doi.org/ $10.2307 / 840886$.

Hadi, Sutrisno. Metodologi Research. Yogyakarta: Fakultas Psikologi Universitas Gadjah Mada, 1990.

Al-Ḥumaydī, 'Abd al-'Azīz ibn 'Abd. Al-Khulafā' al-Rāshidūn Mawāqif wa 'Ibar. Iskandariyah: Dār al-Da'wah, 2005. https://down.ketabpedia.com/files/ bkb/bkb-hi03517-ketabpedia.com.pdf.

Kamali, Mohammad Hashim. 'Ethical Limits on Freedom of Expression with Special Reference to Islam'. Cile Journal, 2014, 42-62. https://www. cilecenter.org/sites/default/files/pdfs/Recommended-Articles-EnglishEthical-Limits-on-Freedom-of-Expression.pdf.

Marwa, Atikah, and Muhammad Fadhlan. 'Ujaran Kebencian di Media Sosial Menurut Perspektif Islam'. Al-Afkar Journal for Islamic Studies 4, no. 1 (4 March 2021): 1-14. https://al-afkar.com/index.php/Afkar_Journal/ article/view/140.

Moeljatno. KUHP Kitab Undang-Undang Hukum Pidana. Jakarta: Bumi Aksara, 2006.

Al-Mun'im, 'Abdullāh ibn Sulaymān ibn 'Alī al-'Abd. 'Fiqh Amīr al-Mu'minīn 'Alī Ibn Abì Tālib fì al-Ḥudūd wa al-Jināyāt wa Athruh fì Tashrī al-Jināî̀ al- 
Yayan Muhammad Royani

Islāmī'. Jāmi'ah Nāyif al-'Arabiyah li al-'Ulūm al-Umniyah , 2004. https://ia903400.us.archive.org/30/items/fiqh07001/fiqh07713.pdf.

Nasution, Johan. Metode Penelitian Ilmu Hukum. Bandung: Mandar Maju, 2008.

Al-Rāọī, Sharīf. Nahju al-Balāghah. Beirut: Dār al-Ma'rifah, n.d.

Radhi, Syekh Syarif. Nahjul Balaghah, Puncak Kearifan Sepanjang Masa. Yogyakarta: Diva Press, 2020.

Rokhmad, Abu. Ușūl Fiqh Metodologi Ijtihad Hukum Islam. Semarang: Varos Mitra Utama, 2002.

Al-Sa'd, Ghassān. Huqūq al-Insān 'ind al-Imām 'Alī ibn Abī Ṭālib 'Alayh al-Salām Ru'yah 'Ilmiyah. Baghdad, 2008. http://www.alnoor.se/article.asp?id= 58783.

Al-Ṣamad, Ḥammad Muhammad 'Abd. Nizām Al-Hukm fi 'ahd al-Khulafä' alRāshidīn. Beirut: Mu'assasah al-Jāmi' 'iyyah li al-Dirāsāt wa al-Nashr wa alTawzì', 1994.

Al-Shallabi, 'Alī Muhammad. Biografi 'Alī ibn Abì Tâalib. Jakarta: Ummul Qura, 2017.

Shaybah, Ibn Abī. Al-Mușannaf, 1986.

Al-Shirbīn̄ī, Muhammad al-Khațīb. Mughnī al-Muhtāj. Beirut: Dār Al-Kutub Al'Ilmiyyah, 2000.

Soekanto, Soerjono, and Sri Mamudji. Penelitian Hukum Normatif Suatu Tinjauan Singkat. Jakarta: RajaGrafindo Persada, 2011.

Sofian, Yayan. Tarikh Tasyri' Sejarah Pembentukan Hukum Islam. Jakarta: Rajaw'Alī Press, 2018.

Al-Ṭabarī, Muḥammad ibn Jarīr. Tārīkh al-Umam wa al-Mulūk. Beirut: Dār alFikr, 1987.

Wardani, Yani'ah, and Ekawati Ekawati. 'Ujaran Kebencian Berbasis Agama: Kajian Persepsi, Respon, dan Dampaknya di Masyarakat'. Buletin Al-Turas 26, no. 1 (10 February 2020): 153-71. https://doi.org/10.15408/ BAT.V26I1.13698.

Al-Wāsiți, 'Alī ibn Muhammad al-Layth. 'Uyūn al-Hukm wa al-Mawā'íz. Dār alHadìth, 2000. https://hz.turathalanbiaa.com/public/3103.pdf.

Al-Zuhaylī, Wahbah. Al-Fiqh al-Islāmī wa Adillatuh. 2nd ed. Damaskus: Dār alFikr al-'Arabī, 1985. 